\title{
The Revived Self Through Nature in Atwood's Surfacing
}

\author{
Anegbe Endurance, Ruzbeh Babaee*, Abdulhameed A. Majeed \\ Faculty of Modern Languages and Communication, University Putra Malaysia, \\ 43400 Serdang, Selangor Darul Ehsan, Malaysia \\ *E-mail address: rbabaei30@yahoo.ca
}

\begin{abstract}
This paper attempts to look at Margret Atwood's Surfacing (1972) which happens to be one of her widely read works via one of the concept of sense of place. In Surfacing, the narration was divided into three parts: firstly, the home coming that is returning back to the place she was born in; secondly, the camping on the island in the cabin and searching for her missing father; and finally, the selfrediscovery via her stay on the Island. The underlying issue, therefore, focuses on the unnamed narrator's life transformation on the Island which gives her the privilege to see things from a different perspective. This vividly revealed the protagonist identification with life on the island, putting on a new identity and refusing to be a victim. This was made possible via her absorption to the island which helps to speed-up her revived self.
\end{abstract}

Keywords: Revived Self; Sense of place; Identity; Home; Nature; Topophilia

\section{INTRODUCTION}

Within the purview of this study, more concentration will be attuned to one of the concept of ecocriticism that is "sense of place". Different folks have different meaning attached to the definition of this concept; what may be a place to one might, on the other hand, be a space to another; it all depends on the individual interpretation of sense of place.

Sense of place is said to be defined as the identity, significance, meaning, and intention of felt value that are given to places by individuals (Pred 1983) as a result of experiencing it over time (Relph 1976; Tuan 1977). Sense of place is said to have two distinctive meanings within the purview of geography. It is sometimes seen from the standpoint of a place "that is memorable or distinctive, having a high image ability" (Lynch 1960, 1972), or it could, therefore, be seen as more commonly, that is viewed as "the consciousness that people themselves have of places, that possess a particular significance for them, either personal or shared" (Gregory 1991: 425).

Dwelling in a place can be said to be a prerequisite to really have a good sense of place, though we can admire a place from a distance, but the connection will be well achieved when we dwell in the place where we are connected with. According to Heidegger, "to dwell is to preserve things in their peace, to spare them actively from anything that might disturb them that might make them different from what they are" (qtd. in Hay 2002: 160). It becomes 
therefore imperative at this junction to state here, in other to keep a place, you as an individual has a great sense towards, certain criteria that should be fulfilled. One of the responsibilities is sparing, which is "tolerance for places in their own essence a willingness to leave places and not try to exploit them" (Relph, 1976: 39).

It has, therefore, become very glary that the interconnection between place, the individual and society, and goes beyond the interaction with the physical landscape and those who share the physical space as it was. This has, therefore, made geographers to assert that sense of place operation is intertwined within three dimensions:

firstly, The perceptual realm of awareness, attitudes and memories; secondly, The emotional realm of feelings preferences, and values; and thirdly, The experiential realm of bodily and sensory contacts, insider/ outsider, and journeys It is an individually based, but group informed, localized, personal means of relating to the world, transforming mere space into personal space (Hay 1988: 160).

Home, within this light could be seen as a good example of a conscious place-full -ness, which is having a strong sense of being in place. It exemplifies the "internal knowledge knowledge of emotion, knowledge of the heart - that comprises sense of place" (Raffan 1993: 4). Home place also establishes a source of reference from which judgments may be made. Tuan describes this as: "Security we are attached to [it]" (3). Thus, there is no place like home. What is home? It is the old homestead, the old neighbourhood, and hometown. He further assert that Love of place, or topophilia "can develop at a grand scale as national identity and even as imperial patriotism, but it can also become manifest at a much more local scale as attachment to neighbourhood or home town" (Simpson-Housley and Norcliffe 1992: 5). Our task is to care for places, "through building or cultivation." It is only through the act of sparing and caretaking, that the notion of home can be properly realised. Relph states, "This is what it means to dwell, which is for Heidegger, "the essence of human existence" (1976: 39). Thus, Heidegger's most significant contribution to the (environmental) concept of home can be seen through his insistence upon the need to live authentically, to be at home, and to take responsibility for the defence of that home in all aspects - human, natural, and the intangible particulars that constitute a place's essence. Accordingly, a place about which one feels so deeply must become a field of care - to love and care for a place entails more than mere affectionate regards (or words); it must also come with a sense of responsibility to that place. However, to passively witness the destruction of one's home is to fail in one's duty to take care for one's dwelling place.

The experience of the home becomes then foundational. However, as Vincent Vycinas puts it, home nowadays is a "distorted and perverted phenomenon" (1961: 85), where it is equated to a house; instead, home can actually be anywhere. The home, as Relph states, "is the foundation of our identity as individuals and as members of a community, the dwelling place of being [it] is an irreplaceable centre of significance" (1976: 39-40), a place where fulfilment, self-discovering and productivity is unaltered and enhanced

Nevertheless, the sense of place and the place of human in a place cannot be over emphasized, or rather under flogged; they are likening to a two sided coin which can never be separated from each other. A place becomes just a space when human are not in the right place to tender, care or rather appreciate the nature, meaning both need each to facilitate the ecosystem of symbiotic relationship which is one of the core trait of ecocriticism. This is the human-place relationship that can only be attained with the human appreciation of a place, which is then transformed into home. 
A sense of place tends to breed home in the human mind and alludes that home itself is the foundation of identity and the dwelling place of being. Thus, a place is not only a specific geographical coordinate that one identifies as home, rather: A multi-layered structure that entails feelings and shared identities. It is shared identities because a place itself cannot stand alone in enabling a sense of identification. It is the presence of human beings within a place that facilitates this phenomenon (Lopez, 1997; Hay, 2002; Davidson, 2007).

\section{REVIVED SELF AND SENSE OF PLACE}

Atwood's Surfacing revolves around an unnamed commercial artist who came in search of her lost father on the island, in the company of her boyfriend Joe, and a married couple Anna and David .On the way to the island; she stopped over in a village near her father's island, to visits her father's friend- Paul. This visit was in an attempt if Paul could provide her with any useful information of her father's location. On her entourage was a guy named Evans who guided the narrator's and her friends to the island. During the narrator's search for clue of her father, she discovered that her father is still alive but has gone insane. In the mist of contemplating on her next move, David thought it would be wise to extend their stay by one more week. She also agrees, though she secretly fears her crazy father's resurfacing might not be palatable, or might even send him back into the woods, because of their presence in his abode.

The protagonist realises the gap between her natural self and her artificial construct. This compels her isolation from the noisy urban setting. It could also be seen as a gradual process of her rediscovery of her inner self, which was made possible through her absorption to nature, alluding to the definition of place, opposed to space, expresses a strong affective bond between a person and a particular setting (Sime 1986: 31). In other words, place is mixed with human values and principles. As a result, place is a particular space which is covered with meanings and values by users.

In the course of her stay on the island, the protagonist finds the ample time to have a close examination of her boyfriend Joe, before deciding if to move on with him. Indeed, her coming to the island did help in resolving some questions, so as not to be caught off guard like her pervious relationship. Then, she comes to the understanding that: "He's good in bed, better than the one before; he's moody but he's not much bother, we split the rent and he doesn't talk much, that's an advantage" (Atwood 39). Such understanding necessitated her acceptance.

Although she regretted her formal marriage, which she felt was manned as a result of their putting pen to paper, signing some names, which had changed everything because much was expected from each other now: "I married him, he married me, and we committed that paper act. I still don't see why signing a name should make any difference but he began to expect things, he wanted to be please. We should have kept sleeping together and left it at that" (Atwood 36)

Her rediscovered identity through nature spews her to study Anna and David's marriage that, after nine years, was still going strong, not really because Anna was older than her; maybe "they must have some special method, formula, some knowledge I missed out on" (Atwood 36). Her curiosity once again compelled her to Anna while they were on an adventure trip on the island, and thus asked her a simple question "how do you manage it" said the narrator, "manage what? "answered Anna, "You just make an emotional commitment, it was like skiing, you couldn't see in advance what would happen but you had to let go" (44). In resolution within 
her, she began to contemplate on what she had let go or what would not have let go. She thought her previous relationship never worked out because she was too buried in it.

The statement "what to let go" foreshadowed her final resolution to let go of her friends, boyfriend, Joe, and the city life just to remain on the island, because she does not want to make same mistakes as before, since she has gotten the secret from Anna, she has now decided to marry nature, which thus helped her in discovering her true self to remain on the island. Although she was upset with her father to have vanished without any trace, she never questioned the rationale behind her father decision to remain in isolation on the island. This could also be seen as another catalyst that influenced her to remain on the island.

In part two of this novel which is an extension of part one; we saw how the island influenced female characters, Anna and the narrator, in their interpretation of men, most especially during sex. Men have this assertion that "love without fear, sex without risk "(Atwood 79), this notion has often been used by men to subdue them, which was later coined by the female characters, as "love with precautions" (Atwood 79). This foreshadowed what happened in part three, where she had to deny Joe and David who had the opportunity to have sex with her, because she feared to get pregnant. In fact, pregnancy within this context does not really mean it is an abomination per se, but the process of child birth, which the narrator tends to dislike:

\begin{abstract}
After the first I didn't ever want to have another child, it was too much to go through for nothing, they shut you into a hospital, they shave the hair off you, tie your hands down and they don't let you see, they don't want you to understand, they want you to believe it's their power, not yours .They stick needles into you so you won't hear anything, you might as well be dead pig, your legs are up in a metal frame, they bend over you, technicians, mechanics, butchers, student clumsy or snickering practicing on your body, they take the baby out with a fork like a pickle out of a pickle jar. After that they fill your veins up with red plastic, i saw it running down through the tube. I won't let them do that to me ever again. (79)
\end{abstract}

The thought of the pain has over time deter her from doing it, not until she discover the animal's ways of giving birth which thus influence her to accept Joe to do it with her. "This time, the baby will slip out easily as an egg, a kitten, andI will lick it off and bite the cord, the blood returning to the ground where it belongs." (Atwood 165). All of these we saw in her present disposition, as a result of her closeness to nature, which thus helped her to renew her dead instinct which has be inactive before her long journey home.

Her coming home in search of her father rekindles in her the sense of self and place. As in one of her conversation "the protagonist sees the heron as symbolic of her psychological death"(Atwood 100), this makes her have disgust towards the killing of the bird. This can be compared to unfair treatment of nature which can be liken to oppression of women by men, women liken with fertility and men cause environment abuse, which has long been a natural trend, even more pronounced in ecostudy, which tends to depict in vivid terms the harsh nature of man towards nature "Why had they strung it up like a lynch victim, why didn't they just throw it away like the trash? To prove they could do it, they had the power to kill otherwise; it was valueless. The only relation they could have to a thing like that was to destroy". (Atwood 149). This was also heightened after her abortion; she (protagonist) comes to develops deep sense to the flora and fauna and realizes that, her disillusionment can only be overcome via her attachment to nature: "Human beings are not radically separate from nature; that is the 
fulfilment of our humanity is profoundly linked with learning to appreciate the nature within us and without". (43).

Regarding sense of place, individuals have the opportunity to nurture the place, not just to exploit the place. Overtime, man has been the worst enemy to nature, environmentally violating the landscape. This was depicted by Atwood during the journey home; she discovers that, "nothing is the same again. I don't know the way anymore" ( Atwood 10), this occur by the virtual of her placelessness, that is loss of sense of place. On the other hand, the destructive nature of human has violated the landscape via technological onslaught, which has made the protagonist of the novel alienated from the landscape of her country, not knowing her way around the country of her birth. "The old roads have long been closed; the new roads are not traceable. The trees will never be allowed to grow tall again, they are killed as soon as they are valuable, big trees are scarce as whale" (Atwood 55). This was again depicted to state that sense of place requires nurture.

Nature is supposed to be nurtured not to be hunted down, as Vandana Shiva points out; it is not hunting which leads to a violent relationship with nature: "it is the elevation of hunting to the level of ideology which does so" (Shiva 50). This was born out of Atwood's assertion of the difference between natural predation and the hunting done by the human. This act has been seen from a self-destructive perspective, which on the long run alienated the human from the natural world, meaning when you are alienated from the natural world, you are invariably displaced, and when you are displaced, you lost the sense of place.

The protagonist's link to nature brought that sense of life back, surviving on mushroom, plants and berries. Then, she feels a total change in her life completely:

Through the trees the sun glances; the swamp around me smoulders, energy of decay turning to growth, green fire. I remember the heron; by now it will be insects, frogs, fish and other herons. My body also changes, creature in me, plant-animal, sends out filaments in me, I ferry it secure between death and life, I multiply." (Atwood 217).

Her changes were clearly depicted to the extent that you could see remarkable changes between the character you saw at the outset of the story and the character you are seeing now. She virtually withdrew from the outside civilisation to embrace life on the island which was now her immediate surroundings. This was resounded in the narrator's total absorption into the life on the island and her relation and interaction with nature and animals somehow led to distortion in her relationship with the human: "I lean against a tree; I am a tree-leaning" (Atwood 236). Furthermore, she feels angry at the sight of her friends who came to look for her, with the feeling that they have come to disturb her peace while in the process of final absorption to nature, with her clothes off, walking bare foot, not having anything to do with metal touched by human being:

That is the way they are, they will not let you have peace, they don't want you to have anything they don't have themselves in another. I stay at the bank resting licking the scratches; no fur yet on my skin, it's too early. (Atwood 192)

She decided to stay back to nurture her baby growing in her womb, she does not know whether the baby is male or female, but her decision speaks better of her intention to stay back "I cannot know yet; it's too early. But I assume it: if I die it dies, if I starve it starves with me. It might be first one, the first true human; it must be born, allowed" (Atwood 250). The 
determination of the protagonist to deliver the baby shows her revived self as a result of her closeness to nature not just to nature per - se, but her connection to the place which has indeed enhanced her conception.

The narrator draws our attention to the killing of heron, and the detonation of an explosion at the lake by the American's who came for fishing. All this harmful act done to the environment makes her feel hurt, because the environment has now become so part of her. She felt disgusted by some senseless beings like, Joe and David filming of the fish's innards. She does not want to kill the fish Indeed she seems to have desisted cruel treatment of nature, but to resort "I couldn't anymore, I had no right to, we don't need it, our proper food was tin cans. We were committing this act, this act. Violation, for pleasure, recreation they call it. (Atwood 153).

The protagonist's subsequent tenderness of heart and nature was again heightened when she had to release a frog to the lake. This scene reawakens the memories of her brother who bottled frogs which she releases as well. Such incident retrospectively gives us a clue of her activities as children, when she drew rabbits with colored- houses, and her brother drew war and death. This in somewhat affected their present disposition, as she is more of the nature nurturer with a high sense of place buther brother is given to violating nature:

\begin{abstract}
Slowly I retrace the trail. something has happened to my eyes, my feet are released, they alternate, several inches from the ground .I'm ice-clear, transparent, my bones and the child inside me showing through the green webs of my flesh, the ribs are shadows, the muscles jelly, the trees are like this too, they shimmer, their cores glow through the wood and bark. The forest leaps upward, enormous, the way it was before they cut it, columns of sunlight frozen ,the boulders float, melt, everything is made of water, even the rocks........ break out again into the bright sun and crumple, head against the ground. I am not an animal or tree, I am the thing in which the tree and animals move and grow, I am a place (Atwood 175).
\end{abstract}

The double stance of the narrator was another indicator that was vividly obvious during the formation of the identity of the protagonist, which is aforementioned above. In an attempt to get rid of the past, (the destructive nature of human), so as to forgone the past to concentrate on her new identity attached place, she first cast off the ring into the fire to burn, though the ring cannot burn, but her blood will thus melt off to purify herself of the past. This thus signifies her separation from the civilization "everything from history must be eliminated" (181). Those she could not break, she threw on the floor. According to Janice Fiamengo, in her article "Postcolonial Guilt in Margret Atwood's Surfacing", "the Canadian bush is a pristine space, the green world of escape and self-revelation (3); this was mirror against the backdrop of the urban life which has so consumed the protagonist to the extent that she cannot even hear her thought, or even balance her long sought self, which was only rediscovered as a result of her return to the island.

The depiction of tension in the relationship between Anna and David reflects the dominating attitude of men over women, as David tried to humiliate Anna. David has forcefully asked Anna to go nude, to strip off her clothes from the movie Random Simple; he even refers to her as daring, a good girl so he can take picture of her. This again shows the rate of destruction that turns the forest naked, nude, and strip of all her maturity only to leave it barren without any care.

With the protagonist's determination to give birth to the child, Atwood has hinted that germination will take place implying that both women and nature will be protected if they 
defend themselves against the onslaught of men whom could be seen as hindrance to complete absorption to a place. She is quiet aware that men's domination of women is deep and systematic. Many men and women think that it is something natural and accepted throughout the world. The oppression of women is so deeply embedded in our societies and our psyches as Petra Kelly observes "Women suffer both from structural oppression and from individual men" (1984: 113). But the heroine would be different, as she would not allow herself to be dominated by men as the symbol of civilisation. She is very well aware that "the ultimate result of unchecked, terminal patriarchy will be ecological catastrophe" (Kelly 118). That is why she becomes chummy with Joe (though he belongs to male caste), who according to her estimate is a pro-feminist man. Like a true ecologist, she makes the earth her literal home for she knows that in the natural world all life is interrelated, teeming with diversity and complexity. She is not afraid of any one.

There is no one to boss over her and violate her physique. She throws away all her civilization as it is destroying the biosphere. She may recreate a culture that respects to seek harmony with nature. Those whom she has known are living in the city now, in a different time. She remembers her man, the "fake husband" for whom she now feels nothing but sorrow. She totally relies on Mother Earth.

\section{CONCLUSION}

The sense of place has indeed revived the protagonist whose dissatisfaction of urban life couples with the destructive nature of human to nature, and spews an inner awaken that helps the revival process, enhancing her love for Mother Nature. Indeed, the place of nature helped the protagonist rediscover her true identity and home.

\section{References}

[1] Atwood M. (1998). The Surfacing. New York: Random House, inc.

[2] Gregory D. (1991). Sense of Place’ The Dictionary of Human Geography, eds R.J. Johnston, D. Gregory and D.M. Smith. Oxford: Basil Blackwell.

[3] Hay R. B. (1988). Trumpeter, 5(4); 159-164.

[4] Kelly P. (1984). "Women and Power." Ecofeminism: Women, Culture, Nature Ed. Karen J. Warren. Bloomington And Indianapolis: Indiana University Press, 112-19.

[5] Pred A. (1983). Journal for the Theory of Social Behaviour, 13(1); 45-68.

[6] Relph E. (1976). Place and Placelessness. London: Pion

[7] Seamon F. (1979). A Geography of the Lifeworld: Movement, Rest and Encounter. New York: St. Martin's Press.

[8] Shiva V. (1998). Staying Alive: Women, Ecology and Survival in India . New Delhi: Kali for Women.

[9] Simpson-Housley P., Norcliffe G. (1992). A few Acres of Snow: Literary and Artistic Images of Canada. Toronto: Dundurn Press.

[10] Hughson J., Ramón S. (2011). Acta Sociologica, 54(3); 283-295. 
[11] Tuan Y. F. (1974). Topophilia: A Study of Environmental Perception, Attitudes and Values, New Jersey: Prentice Hal.

[12] (1977). Space and Place: The Perspective of Experience. Minneapolis: University of Minnesota. 